\title{
PENGEMBANGAN MODUL PRAKTIKUM KIMIA LINGKUNGAN BERBASIS GREEN CHEMISTRY PADA MATA KULIAH KIMIA LNGKUNGAN
}

\section{DEVELOPMENT OF GREEN CHEMISTRY BASED ENVIRONMENTAL CHEMISTRY PRACTICUM MODULE IN ENVIRONMENTAL CHEMISTRY COURSE}

\author{
Syarifa Wahidah Al Idrus*, A.A. Purwoko, Saprizal Hadisaputra, Eka Junaidi \\ Program Studi Pendidikan Kimia, Universitas Mataram, Indonesia \\ *Email: syarifaidrus@unram.ac.id
}

Diterima: 26 November 2020. Disetujui: 27 November 2020. Dipublikasikan: 9 Desember 2020

\begin{abstract}
Abstrak: Perkembangan teknologi yang sangat pesat berdampak negatif terhadap kondisi lingkungan. Hal ini mengkhawatirkan semua pihak, tak terkecuali praktisi Pendidikan. Kontribusi dalam bidang Pendidikan yang dapat dilakukan adalah dengan merancang proses pembelajaran yang peduli terhadap lingkungan. Dalam pendidikan kimia, penerapan prinsip Green Chemistry dalam kegiatan laboratorium diharapkan mampu menjawab tantangan tersebut. Penelitian ini bertujuan untuk mengembangkan sebuah Modul Praktikum kimia lingkungan berbasis Green Chemistry yang dapat digunakan mahasiswa sebagai penuntun pelaksanaan praktikum yang aman dan ramah lingkungan pada mata kuliah Kimia Lingkungan . Metode penelitian ini adalah Research and Development (R\&D),dengan prinsip pengembangan media menurut William W. Lee dan Diana L. Owens . Sasaran penelitian ini adalah kelayakan modul praktikum berdasarkan penilaian ahli (dosen Kimia) dan respon mahasiswa. Hasil penelitian dianalisis menggunakan metode analisis deskriptif kuantitatif. Analisis data menunjukkan penilaian dosen kimia dengan kategori "sangat baik" dengan rerata skor diatas 3,4. Respon mahasiswa menunjukkan modul praktikum sangat efektif dengan respon positif dengan rata rata setiap aspek diatas 0,49. Jadi, Modul Praktikum kimia lingkungan berbasis green chemistry yang dikembangkan sangat layak untuk diimplementasikan dalam pembelajaran Kimia lingkungan.
\end{abstract}

Kata Kunci : Pengembangan, Modul Praktikum Kimia Lingkungan, Green Chemistry

\begin{abstract}
The development of technology has a negative impact on environmental conditions. This matter worries all parties, including education practitioners. Contribution in the field of education that can be made is by designing a learning process that cares about the environment. In chemistry education, the application of Green Chemistry principles in laboratory activities is expected to be able to answer these challenges. This study aimed to develop a Green Chemistry-based environmental chemistry Practicum Module that students can use as a guide for implementing safe and environmentally friendly practicum in Environmental Chemistry courses. This research method was Research and Development (R\&D), with the principle of media development according to William W. Lee and Diana L. Owens. The target of this research was the feasibility of the practicum module based on expert assessment (Chemistry lecturers) and student responses. The research results were analyzed using quantitative descriptive analysis method. The data analysis showed that the chemistry lecturer assessment was in the "very good" category with an average score above 3.4. Student responses showed that the practicum module was very effective with a positive response with an average of each aspect above 0.49 . So the green chemistry-based environmental chemistry practicum module developed was very feasible to be implemented in environmental chemistry learning.
\end{abstract}

Keywords : Development, Environmental Chemistry Practicum Modules, Green Chemistry

\section{PENDAHULUAN}

Indonesia sebagai negara berkembang terus mengikuti perkembangan teknologi. Pesatnya teknologi selain berdampak positif juga berdampak negatif terhadap kondisi lingkungan. Hali ini juga menjadi masalah yang cukup serius di Indonesia. Kontribusi Indonesia dalam menyumbangkan emisi ke lingkungan menempati urutan ketiga di dunia [13]. Sebagai upaya untuk mengatasi masalah lingkungan, Indonesia muali mencanangkan pembangunan berkelanjutan. Konsep ini bertujuan untuk memenuhi kebutuhan saat ini dan kebutuhan yang akan datang untuk generasi penerus bangsa. Pembangunan berkelanjutan telah dicanangkan untuk segala aspek kehidupan, sehingga konsep ini diterapkan dalam segala bidang, termasuk
Pendidikan. Aktivitas manusia dalam memenuhi kebutuhan tidak memperhatikan dampaknya terhadap masa depan lingkungan [4,5]. Hal ini disebabkan karena masyarakat Indonesia minim pengetahuan tentang pembangunan berkelanjutan. Nilai-nilai pembangunan berkelanjutan dapat ditanamkan pada generasi muda melalui bidang Pendidikan. Pendidikan kimia merupakan salah satu bidang pendidikan yang dapat berkontribusi positif atau negatif dalam pembangunan berkelanjutan. Kontribusi negatif jika Pendidikan kimia dalam proses pembelajarannya tidak menerapkan prinsip prinsip ramah lingkungan, sehingga setiap proses kimia yang dilakukan akan menimbulkan bahaya. Peran positif Pendidikan kimia dalam pembangunan berkelanjutan pada penanaman konsep dan aplikasi dalam bentuk praktikum. Tanpa 
penanaman nilai nilai pembangunan berkelanjutan, praktikum kimia dapat merusak lingkungan.

Kegiatan praktikum di laboratorium merupakan bagian yang penting dalam pembelajaran kimia termasuk kimia lingkungan. Metode praktikum sangat penting untuk matakuliah kimia lingkungan, biasanya dilakukan di laboratorium dan lapangan untuk observasi kondisi lingkungan sekitar. Praktikum merupakan cara penyajian materi yang cukup efektif karena mahasiswa atau siswa mengalami dan membuktikan sendiri materi yang telah dipelajari dengan cara melakukan kegiatan langsung, sehingga mahasiswa atau siswa dapat membangun pemahaman sendiri dengan menitik beratkan pada pengalaman langsung [6]. Untuk melakukan kegiatan praktikum diperlukan sarana penunjang laboratorium.

Pentingnya peran laboratorium dalam pendidikan ternyata memunculkan banyak permasalahan dalam pengelolaan laboratorium, terutama laboratorium kimia. Permasalahan- tersebut antara lain: 1) mahalnya harga bahan dan alat kimia menyulitkan proses pengadaan [7] 2) tingkat bahaya yang tinggi dari bahan kimia dalam laboratorium [8], sehingga mucul kekhawatiran praktikan dalam melakukan praktikum Bahan-bahan berbahaya yang sering dikhwatirkan praktikan antara lain: $\mathrm{HgCl}$, $\mathrm{AgNO} 3, \mathrm{CuSO} 4, \mathrm{MnO}, \mathrm{Pb}$ asetat [9]. Masalah laboratorium diatas akan menghasilkan limbah yang membahayakan lingkungan. Menurut [10], sebagian besar limbah laboratorium dapat mencemari lingkungan. Kondisi ini sangat bertolak belakang dengan tujuan matakuliah kimia lingkungan untuk menyiapakan mahasiswa yang sadar lingkungan.

Mata kuliah Kimia Lingkungan merupakan salah satu matakuliah yang berada didepan dalam ikut peduli terhadap lingkungan bertujuan untuk memberikan pengetahuan dan wawasan kepada mahasiswa tentang berbagai permasalahan lingkungan baik lingkungan perairan, udara dan tanah dari segi tinjauan kimia. Selain itu mahasiswa diharapkan dapat menjelaskan berbagai proses perubahan kimia yang berlangsung di lingkungan dan berbagai aktivitas yang menyebabkan terjadinya penurunan kualitas lingkungan serta penanggulangannya. Diharapkan dengan mengikuti mata kuliah ini mahasiswa dapat meningkatkan kesadarannya terhadap lingkungan mulai dari diri mereka dan dapat menyelesaikan permasalahan lingkungan yang ada disekitarnya. Namun, dalam pelaksanaannya metode praktikum dalam matakuliah kimia lingkungan dapat membahayakan praktikannya dan juga menghasilkan limbah karena penggunaan bahan kimia berbahaya. Kondisi ini sangat bertolak belakang dengan tujuan matakuliah kimia lingkungan untuk menyiapakan mahasiswa yang sadar lingkungan. Oleh karena itu, penelitian ini bertujuan untuk mengembangkan modul praktikum dengan prinsip Green Chemsitry dan menilai kualitasnya berdasarkan penilaian dosen kimia dan mahasiswa.
Pendekatan Green Chemistry adalah pendekatan yang termasuk dalam Education for Sustainable Development (ESD) [11-13]. Pendekatan ini dapat diterapkan untuk mewujudkan kegiatan laboratorium yang aman dan ramah lingkungan. Green chemistry mempunyai 12 prinsip yang dapat dijadikan acuan dalam merancang kegiatan kimia yang aman dan menghasilkan produk tanpa limbah berbahaya [14]. Gagasan dari green chemistry konsentrasi pada pengaturan penggunaan bahan kimia, produksi dan evaluasi akibatnya pada lingkungan. Aplikasi dari green chemistry sudah mulai diguanakan dibeberapa aktivitas seperti aktivitas di sekolah [15], dan mengintegrasikan green chemistry pada kurikulum kimia [16]. Penelitian ini bertujuan menintegrasikan konsep green chemistry dalam modul praktikum Kimia Lingkungan untuk meningkatkan kreativitas mahasiswa calon guru kimia". Harapan dari penelitian ini calon guru kimia dibekali dengan pengetahuan tentang lingkungan sehingga pembelajaran kimia menjadi lebih bermakna dengan pengembangan keterampilan berfikir kreatif dan perilaku postif terhadap lingkungan.

\section{METODE PENELITIAN}

Penelitian ini dilakukan di Progdi Pendidikan kimia, Universitas Mataram (UNRAM). Desain penelitian ini merupakan Research and Development (R\&D), dengan prinsip pengembangan media menurut William W. Lee dan Diana L. Owens yaitu terdiri dari empat tahapan yakni (1) menyusun sebuah kerangka dari pengembangan alat, pengembangan spesifikasi, dan standarnya; (2) mengembangkan bagian-bagian dari media yang telah dicocokkan dengan kerangkanya; (3) meninjau dan perbaiki produknya; (4) mengimplementasikan produk akhirnya.

Tahap pertama, penyusunan kerangka dari pengembangan modul praktikum dilakukan analisis terhadap kegiatan laboratorium dan isi materi Kimia lingkungan serta studi terhadap prinsip-prinsip pendekatan Green Chemistry. Analisis tersebut bertujuan untuk mengumpulkan informasi terkait seperti kemampuan awal mahasiswa tentang konsep green chemistry. Analisis awal dimulai dengan menganalisis kemampuan awal mahasiswa kimia lingkungan tentang prinsip green chemistry dan mereviu modul praktikum kimia lingkungan. Analisis kemampuan awal mahasiswa dilakukan dengan memberikan soal soal yang terkait prinsip green chemistry. Reviu modul praktikum dilakukan berdiskusi dengan mahasiswa untuk melatih berfikir kreatif mahasiswa. Reviu dipusatkan pada identifikasi prosedur praktikum dan bahan bahan kimia yang digunakan pada kegiatan praktikum yang sesuai atau tidak dengan prinsip green chemistry. Selanjutnya, studi pendekatan Green Chemistry untuk menentukan prinsip Green Chemistry yang sesuai dengan prosedur setiap judul praktikum. Prinsip - prinsip tersebut diharapkan dapat membantu mahasiswa kimia lingkungan untuk mengenal bahan - bahan kimia yang 
aman dan yang berbahaya sehingga tahu cara menggunakannya serta prosesnya yang lebih ramah lingkungan.

Tahap kedua adalah mengembangkan Modul Praktikum yang sesuai dengan kerangka pada tahap pertama. Hasil dari tahap kedua adalah draf 1 atau desain awal modul praktikum. Tahap ketiga adalah meninjau dan memperbaiki modul praktikum sehingga diperoleh draf 2. Draf 2 modul praktikum melalui proses telaah, validasi dan revisi hingga akhirnya menghasilkan draf 3. Proses telaah dilakukan oleh teman sejawat untuk mendapat masukan dan saran mengenai desain awal modul. Kemudian, draf 2 tersebut divalidasikan kepada ahli yaitu dosen Kimia dari Program Studi Pendidikan Kimia, Universitas Mataram. Penilaiannya meliputi tiga aspek yakni petunjuk, isi dan kesesuaian dengan pendekatan Green Chemistry. Tahap ke empat, Draft 3 siap untuk diimplementasikan atau diuji cobakan pada mahasiswa kimia lingkungan semester 6 .

Tujuan dilakukannya uji coba mengetahui respon dan tanggapan mahasiswa terhadap modul yang dikembangkan. Instrumen yang digunakan adalah angket respon mahasiswa.Selanjutnya angket dianalisis dan ditarik kesimpulan tentang kualitas modul yang telah dikembangkan.Data hasil penelitian berupa penilaian dari Dosen Kimia dan respon dari mahasiswa dianalisis dengan cara menghitung rerata skor dan menentukan kriteria interpretasi skor. Indikator kelayakan Modul Praktikum apabila rerata skor hasil penilaian Dosen Kimia lebih dari 3,40 [17].

Tabel 1. Interpretasi skor kelayakan modul praktikum [18]

\begin{tabular}{l|l}
\hline Interval skor & Kategori penilaian \\
\hline $4,20<$ Skor $\leq 5,00$ & Sangat Baik \\
$3,40<$ Skor $\leq 4,19$ & Baik \\
$2,60<$ Skor $\leq 3,39$ & Cukup \\
$1,80<$ Skor $\leq 2,59$ & Kurang \\
$1,00 \leq$ Skor $\leq 1,79$ & Sangat kurang \\
\hline
\end{tabular}

Selain indikator kelayakan yang dilakukan oleh dosen, diambil data indikator keefektifan berdasarkan respon mahasiswa. Modul praktikum yang dikembangkan dikatakan efektif jika rerata skor mencapai lebih dari 0,49 [18].
Tabel 2. Interpretasi Skor Keefektifan berdasarkan respon mahasiswa

\begin{tabular}{l|l}
\hline Interval Skor & Kategori Penilaian \\
\hline 1 & Setuju \\
$0,51-0,99$ & Mendekati Setuju (MS) \\
0,50 & Agak Setuju (AS) \\
$0,01-0,49$ & Mendekati Tidak Setuju (MTS) \\
0 & Tidak Setuju (TS) \\
\hline
\end{tabular}

\section{HASIL DAN PEMBAHASAN}

Penelitian ini bertujuan mengembangkan modul praktikum Kimia Lingkungan berbasis Green Chemistry yang layak dan dapat digunakan oleh mahasiswa calon guru. Hasil dari empat tahap pengembangan modul praktikum ini dapat dijabarkan sebagai berikut:

\section{Data Hasil Penyusunan Kerangka Modul Praktikum (Tahap I)}

Pada tahap pertama diperoleh data analisis reviu modul praktikum kimia lingkungan dan data analisis kemampuan awal mahasiswa kimia lingkungan terhadap konsep Green Chemistry. Data analisis kemampuan awal mahasiswa kimia lingkungan tentang konsep green chemistry sebagian besar berkategori rendah $(<50 \%)$ Kemampuan awal analisis konsep green chemistry dilakukan dengan memberikan soal terkait 12 prinsip green chemistry.

Data analisis reviu modul praktikum kimia lingkungan diperoleh dengan mengajak keikutsertaan mahasiswa berdiskusi tentang modul praktikum yang sudah ada. Hal ini dilakukan agar mahasiswa kimia lingkungan sebagai calon guru kimia ikut serta dalam merancang pengembangan modul praktikum. Selama ini, mahasiswa diberikan panduan praktikum yang sudah siap pakai, sehingga mahasiswa mempunyai keterbatasan dalam memahamai bahan bahan kimia berbahaya dan alat alat laboratorium serta proses kimia yang berbahaya. Berdasarkan hasil analisis terhadap materi Kimia lingkungan yang dijabarkan dalam RPS dirumuskan delapan judul praktikum Kimia lingkungan yaitu mengukur parameter standar kualitas air, pengukuran kadar oksigen terlarut (DO) perairan, pengukuran kadar kebutuhan oksigen biologi perairan (BOD), pengukuran kadar kebutuhan oksigen kimia perairan (COD), pengukuran kadar $\mathrm{CO}_{2}$ dalam perairan, pengukuran daya menggabung asam pada perairan, analisis parameter kualitas tanah dan analisis parameter kualitas udara. Analisis selanjutnya dilakukan studi pendekatan untuk memperoleh atau menyesuaikan prinsip prinsip green chemistry pada setiap judul praktium, seperti terlihat pada table 3 . 
Tabel 3. Prinsip Green Chemistry dalam Modul Praktikum Kimia Lingkungan

\begin{tabular}{l|l}
\hline Judul Praktikum & Prinsip Green Chemistry \\
\hline Mengukur parameter standar kualitas air & $\begin{array}{l}\bullet \text { Sintesis bahan kimia yang tidak berbahaya } \\
\text { merancang zat kimia yang aman } \\
\text { Pengukuran kadar oksigen terlarut (DO) perairan } \\
\text { Pengukuran kadar kebutuhan oksigen biologi perairan yang lebih aman untuk mencegah } \\
\text { (BOD) }\end{array}$ \\
$\begin{array}{l}\text { Pengukuran kadar kebutuhan oksigen kimia perairan } \\
\text { (COD) }\end{array}$ & $\begin{array}{l}\bullet \text { penggunaan pelarut yang lebih aman } \\
\text { Pengukuran kadar } \mathrm{CO}_{2} \text { dalam perairan }\end{array}$ \\
Pengukuran daya menggabung asam pada perairan & \\
Analisis parameter kualitas tanah & \\
Analisis parameter kualitas udara & $\bullet$ pencegahan \\
\hline
\end{tabular}

Dari table diatas terlihat bahwa tiap acara praktikum menerapkan prinsip green chemistry yang berbeda. Acara pertama sampai ke 6 membutuhkan prinsip green chemistry yang sama yaitu sintesis bahan kimia yang tidak berbahaya, merancang zat kimia yang aman, kimia yang lebih aman untuk mencegah terjadinya kecelakaan dan penggunaan pelarut yang aman. Hal ini mengindikasikan bahwa judul pertama ampai ke 6 membutuhkan sintesis kimia dalam percobaannnya sehingga di usahakan agar proses yang akan dilakukan tidak berbahaya bagi praktikan dan lingkungan sekitar. Untuk judul praktikum 7 dan 8, digunakan prinsip pencegahan dan mengurangi derivate kimia. Pada percobaan ke 7 dan 8 yaitu analisis parameter kualitas tanah dan udara, bisa dilakukan dengan prosedur sederhana. Prosedur sederhana disini yaitu dengan memanfaatkan alat dan bahan yang banyak di lingkungan sekitar. Penggunaan bahan bahan sederhana sangat sesuai dengan prinsip pencegahan yaitu lebih baik mencegah munculnya limbah daripada membersihkan limbah. Dan penggunaan bahan bahan alami yang ada dialam akan mengurangi penggunaan derivate kimia.

\section{Data Hasil Pengembangan Modul Praktikum (tahap 2)}

Pengembangan modul praktikum kimia lingkungan dilakukan berdasar hasil kerangka pada tahap pertama. Pada tahap pengembangan modul dibagi menjadi, bagian awal modul terdiri atas (1) sampul modul, (2) kata pengantar, (3) daftar isi, (4) tata tertib, (5) penilaian praktikum, (6) prosedur umum pelaksanaan praktikum, (7) sistematika penulisan laporan, (8) pengenalan alat laboratorium, (9) pendekatan Green Chemistry dan (10) deskripsi praktikum Kimia Lingkungan.

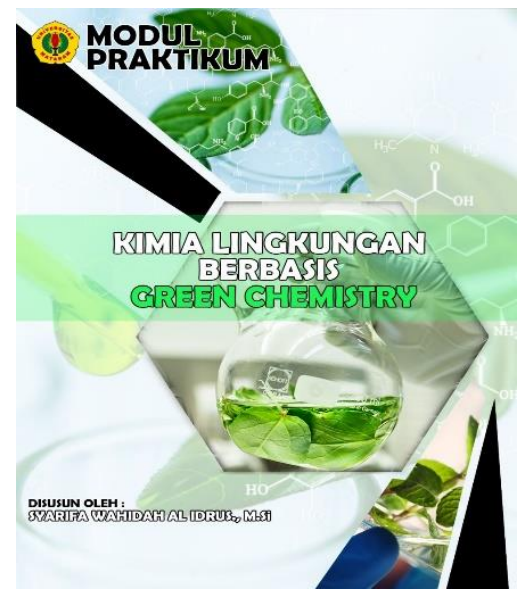

Gambar 1. Sampul Depan Modul

Bagian isi merupakan rancangan setiap judul praktikum yang terdiri atas komponen: (1) judul praktikum, (2) pendahuluan, (3) persiapan, (4) alat dan bahan, (5) prinsip Green Chemistry, (6) prosedur percobaan, (7) tabel data percobaan, (8) analisis/Diskusi, (9) simpulan dan (10) daftar pustaka. Pada umumnya modul praktikum memiliki format: judul praktikum, tujuan, dasar teori, alat dan bahan, langkah kerja, daftar pustaka [19]. Hasil pengembangan tahap 2 ini akan diperoleh draft 1 modul praktikum kimia lingkungan berbasis green chemistry atau desain awal modul. Draft 1 akan masuk ke tahap 3, desain awal modul praktikum akan ditinjau dan direvisi sehingga diperoleh draf 2 .

\section{Data Hasil revisi Modul Praktikum (Tahap 3)}

Pada tahap ini, desain awal modul atau draft 1 modul ditelaah oleh dosen pendidikan kimia UNRAM selaku teman sejawat. Hasil pada tahap ini dijadikan perbaikan modul untuk mendapatkan draft 2 modul. Masukan yang diperoleh dari dosen pendidikan kimia berupa revisi kecil pada bagian isi dan petunjuk praktikum. Salah satu perbaikan draft berdasarkan masukan teman sejawat adalah menggabungkan acara ke 2 dan ke 3 dalam draft modul dalam 1 acara praktikum. Setelah melalui perbaikan akan terbentuk draft 2 modul praktikum 
kimia lingkungan berbasis green chemistry dengan 7 acara praktikum. Langkah selanjutnya, draft 2 akan melewati proses validasi oleh dosen pendidikan kimia FKIP Universitas Mataram. Validasi yang dilakukan meliputi tiga aspek yaitu petunjuk, isi dan kesesuaian dengan prinsip Green Chemistry. Proses validasi juga digunakan sebagai kelayakan modul praktikum yang dikembangkan.

Hasil validasi menunjukkan bahwa Modul Praktikum Kimia lingkungan dengan pendekatan Green Chemistry memperoleh penilaian dari dosen
Kimia pada rentang sangat baik karena mendapatkan skor > 3,4 [17]. Artinya, Modul Praktikum Kimia lingkungan layak untuk diimplementasikan dalam proses pembelajaran mata kuliah Kimia Lingkungan tetapi dengan saran dan revisi kecil di beberapa bagian Modul Praktikum seperti prosedur praktikum, alat dan bahan. Saran yang diberikan validator yaitu tentang perbaikan jumlah bahan yang digunakan. Hasil validasi berdasarkan isi dan penerapan pendekatan green chemistry dapat terlihat pada gambar 2 .

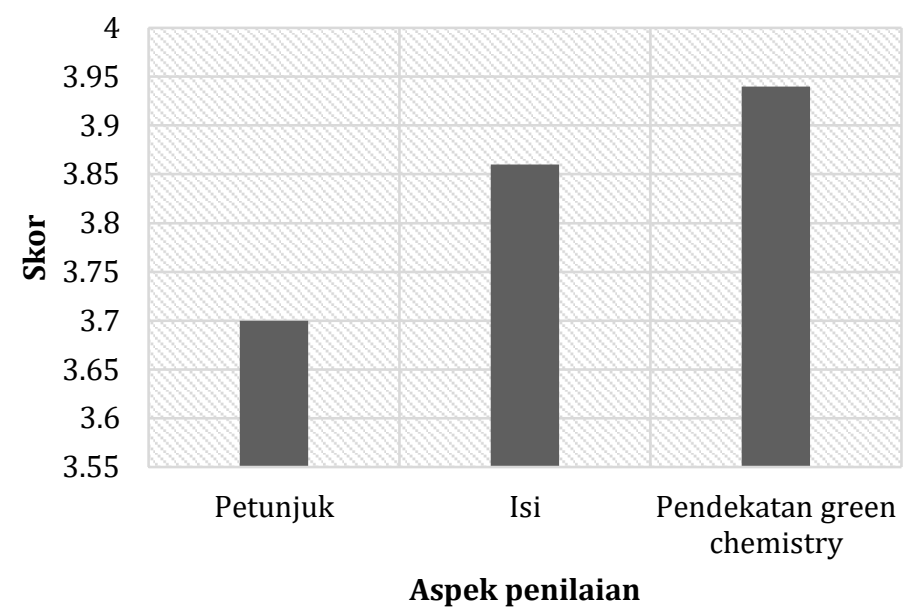

Gambar 1. Hasil Validasi Teman Sejawat Terhadap Modul Praktikum Kimia Lingkungan

Selain validasi dosen, draft 3 modul praktikum kimia lingkungan berbasis green chemistry juga diimplementasikan ke mahasiswa kimia lingkungan semester VI tahun ajaran genap 2019/2020. Implementasi modul dilakukan untuk mendapatkan respon mahasiswa tentang modul praktikum kimia lingkungan berbasis green chemistry. Respon mahasiswa terhadap empat (4) aspek dalam modul praktikum kimia yaitu (1) Kejelasan kalimat dan keterbacaan, (2) Tampilan Fisik Modul, (3) keterlaksanaan praktikum dan (4) Pendekatan Green Chemistry terlihat dalam gambar 2.

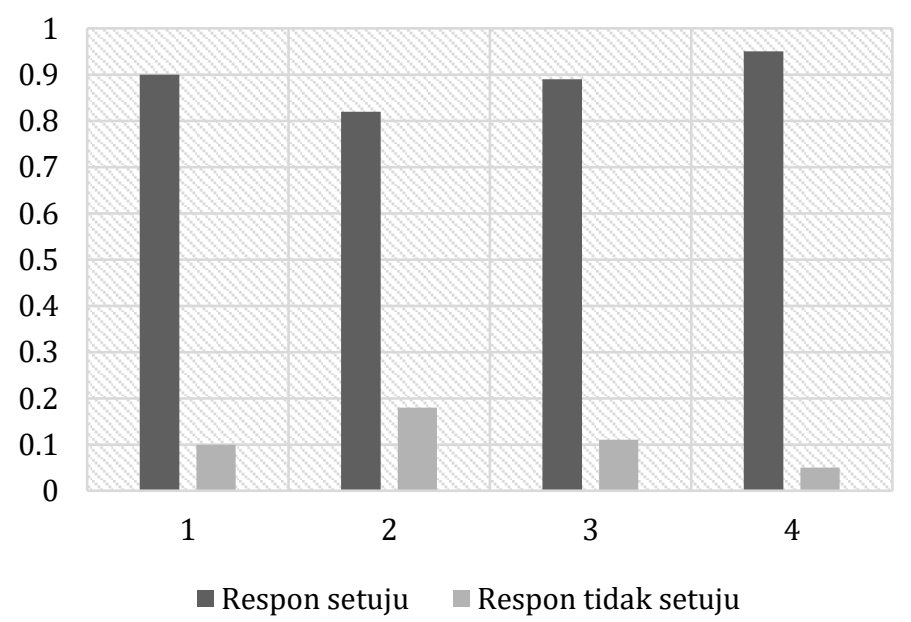

Gambar 2. Data Respon Mahasiswa Terhadap Modul Kimia Lingkungan 
Pada gambar 2, terlihat bahwa respon mahasiswa kimia lingkungan semester VI terhadap modul praktikum kimia lingkungan berbasis green chemistry yang diterapakan pada mata kuliah kimia lingkungan sangat positif. Respon setuju pada aspek "kejelasan kalimat dan keterbacaan" mencapai 0,90. Pada aspek "Tampilan Fisik modul", mendekati setuju 0,82 , aspek "keterlaksanaan praktikum" pada posisi 0,89 dan aspek "Pendekatan green chemistry" ratarata mahasiwa setuju 0,95 . Respon dikatakan positif jika rata rata skor aspek penilaian mencapai lebih dari 0,49 [18]. Respon negatif atau positif akan muncul setelah mahasiswa melakukan dan mengamati aktivitas dengan menggunakan pacaindra dan menilai objek [20]. Aspek tampilan fisik modul mencapai skor terendah, kemungkinan disebabkan kurang proporsional tampilan gambar dalam modul. Aspek pendekatan green chemistry mendapatkan respon yang paling baik. Hal ini disebabkan mahasiswa cukup tertarik dengan prinsip- prinsip green chemistry yang sudah tertuang dalam setiap acara praktikum. Sehingga praktikum kimia lingkungan yang dilakukan aman dan ramah lingkungan, serta tidak menghasilkan banyak limbah.

Berdasarkan data data penilaian teman sejawat dan respon mahasiswa modul praktikum kimia lingkungan telah menunjukkan prosedur praktikum berwawasan lingkungan atau berbasis green chemistry. Modul praktikum kimia lingkungan berbasis green chemistry yang dibuat dengan menerapkan kaidah-kaidah green chemistry yang meliputi pencegahan, atom economic, serta sinetsis kimia dengan mengurangi bahan-bahan yang berbahaya, menghasilkan produk kimia yang aman, dan efesisensi energi dengan mengurangi tahapan reaksi [9]. Penerapan modul praktikum berbasis green chemistry akan memeberikan dampak positif terhadap lingkungan sehingga Mata kuliah kimia lingkungan telah mengikuti Education for Sustainable Development (ESD). Dengan demikian produkproduk praktikum kimia tidak akan mencemari lingkungan dan telah ikut menjaga keselarasan hubungan manusia dengan lingkungan.

\section{KESIMPULAN}

Modul praktikum kimia lingkungan berbasis green chemistry dikembangkan dengan menerapakan 6 prinsip green chemistry yaitu Sintesis bahan kimia yang tidak berbahaya, merancang zat kimia yang aman, kimia yang lebih aman untuk mencegah terjadinya kecelakaan, penggunaan pelarut yang lebih aman dan pencegahan. Acara praktikum dalam modul ini berjumlah 7 kegiatan. Berdasarkan penilaian dosen kimia modul ini berada pada kategori sangat baik dengan rata rata aspek penilaian diatas 3,4. Respon mahasiswa menunjukkan respon positif dengan rata rata skor aspek penilaian mencapai lebih dari 0,49 . Hal ini berarti modul praktikum kimia lingkungan berbasis green chemistry layak digunakan sebagai panduan praktikum pada mata kuliah Kimia
Lingkungan. Harapannya modul praktikum ini menjamin keterlaksanaan seluruh kegiatan praktikum berjalan dengan aman dan ramah bagi lingkungan serta kesehatan. Sekaligus media untuk mengenalkan konsep pengembangan berkelanjutan untuk membekali pengetahuan calon guru kimia tentang lingkungan. Sehingga guru kimia dapat menjadi pendidik yang menghadirkan kegiatan pembelajaran lebih relevan dan responsif terhadap lingkungan.

\section{DAFTAR PUSTAKA}

[1]. Measey, M. (2010). Indonesia: a vulnerable country in the face of climate change. Global Majority E-Journal, 1(1), 31-45.

[2]. Case, M., Ardiansyah, F., \& Spector, E. (2007). Climate change in Indonesia: implications for humans and nature. Climate change in Indonesia: implications for humans and nature.

[3]. Syaukat, Y. (2011). The impact of climate change on food production and security and its adaptation programs in Indonesia. J. ISSAAS, 17(1), 40-51.

[4]. Zelezny, L. C., \& Schultz, P. W. (2000). Psychology of promoting environmentalism: Promoting environmentalism. Journal of Social Issues, 56(3), 365-371.

[5]. Aniela, Y. (2012). Peran Akuntansi Lingkungan Dalam Meningkatkan Kinerja Lingkungan Dan Kinerja Keuangan Perusahaan. Berkala Ilmiah Mahasiswa Akuntansi, 1(1).

[6]. Djamarah, S. B., \& Zain, A. (2006). Strategi belajar mengajar. Jakarta: Rineka Cipta, 46.

[7]. Ari Laksmi, I. G. A. (2014). Analisa Pengelolaan Alat dan Bahan Praktikum pada Laboratorium Kimia: Studi Kasus di SMA N 1 Seririt. eJournal Kimia Visvitalis.

[8]. Dash, S. (2014). Green Chemistry: An Essential of an Hour: A reviw. Asian Journal of Biochemical and Pharmaceutical Research, 2(4), 1-3.

[9]. Redhana, I. W. (2014). Menghijaukan Kurikulum Kimia untuk Mencapai Pembangunan Berkelanjutan. Orasi Ilmiah Pengenalan Guru Besar Tetap dalam Bidang Pendidikan Kimia. Singaraja: Undiksha.

[10]. Singh,A.,Singh, S., Singh, N. (2014). Green Chemistry: Sustainability an Innovative Approach. Journal of Applied Chemistry, 2(2): 77-82.

[11]. Amyyana, A. H., Paristiowati, M., \& Kurniadewi, F. (2017). Pirolisis Sederhana Limbah Plastik dan Implementasinya Sebagai Sumber Belajar Berbasis Education for Sustainable Development (ESD) Pada Pembelajaran Kimia. JRPK: Jurnal Riset Pendidikan Kimia, 7(1), 14-21.

[12]. Burmeister, M., Rauch, F., \& Eilks, I. (2012). Education for Sustainable Development (ESD) 
and chemistry education. Chemistry Education Research and Practice, 13(2), 59-68.

[13]. Hamidah, N., Prabawati, S. Y., Fajriati, I., \& Eilks, I. (2017). Incorporating sustainability in higher chemistry education in Indonesia through Green Chemistry: Inspirations by inquiring the practice in a German University. International Journal of Physics \& Chemistry Education, 9(1), 1-7.

[14]. Karpudewan, Mageswary., Ismail, Zurida., \& Mohamed, Norita. (2011). "Green Chemistry: Educating Prospective Science Teachers in Education for Sustainable Development at School of Educational Studies, USM". Journal of Social Sciences. Vol. 7, No. 1, pp. 4250.

[15]. Aubrecht, K. B., Padwa, L., Shen, X., \& Bazargan, G. (2015). Development and Implementation of A Series of Laboratory Field Trips for Advanced High School Students to Connect Chemistry to Sustainability. Journal of Chemical Education, 92(4), 631-637.

[16]. Karpudewan et al., (2015) The Effects of "Green Chemistry" on Secondary School Students' Understanding and Motivation. The Asia Pasific Education Researcher 24, 35-43.

[17]. Riduwan. (2010). Dasar-dasar Statistika. Bandung: Alfabeta.

[18]. Sugiyono. (2012). Metode Penelitian Pendidikan (Pendekatan Kuantitatif, Kualitatif, dan R\&D). Bandung: Alfabeta.

[19]. Fidiana, L., Bambang, S., dan Pratiwi, D. (2012). Pembuatan dan Implementasi Modul PraktikumFisika Berbasis Masalah untuk Meningkatkan Kemandirian Belajar Siswa Kelas XI. Unnes Physics Education Journal, 1(1):3844.

[20]. Hidayati, T., Sunyoto, E., Nugroho, dan Sudarmin. (2013). Pengembangan Tes Diagnostik untuk Mengidentifikasi Keterampilan Proses Sains dengan Tema Energi pada Pembelajaran IPATerpadu. Unnes Science Education Journal, 2(2):311-319. 